\title{
Occupied reflections: audience as performers
}

\author{
Sara Carvalho
}

Universidade de Aveiro | Portugal

Instituto de Etnomusicologia - Centro de Estudos em Música e Dança (INET-md) | Portugal

\begin{abstract}
New music is often perceived as challenging, and many times generates controversial opinions. Nevertheless, it allows for some non-obvious relationships between composers, performers, and listeners. Finding more effective ways to engage listeners into new music could be an alternative way to reach out to further audiences. This paper aims to discuss and give examples of how the audience was integrated as a performer in a new music performance, more specifically in the piece "occupied mirrors", for toy piano and audience (composed by the author of the paper). The piece was thought through and planned in such a way that it invited the audience to become active performers, part of the musical plot as music makers. Conclusions suggest that what was asked from the audience opened up a unique new music experience, as they had to follow instructions and actively participate in the construction of the sound.
\end{abstract}

Keywords: New music; Composition; Toy piano; Audience; Performance 
s music is a temporal art form, it is often very difficult to retain all the musical ideas of a
piece, as "Music unfolds in temporal experience; it is always continuous and in flux.
Still, we have the definite impression that music involves a characteristic experience, principally one in which the flow of temporal events is organized in some way" (SERAFINE, 1988, p. 36). The trilogy between composer/performer/listener (composition/interpretation/perception) proposed by Kendall and Carterette (1990) reflects on the idea of how a musical goal/expression could be conveyed. The composer uses notation to create music, which is given to the performer who transforms it into the sound that is received by the listener; also, musical composition has been generally characterized as "some kind of intellectual property to be delivered securely from composer to listener" (COOK, 2001, p. 6). Although for past centuries this seemed to be the rule, nowadays not all music works like this.

Traditionally, musical concerts have the audience as non-performative listeners, passive observers and receivers of the creation, "and the audible product is presented to the anonymous listener who is physically detached from the musical activity, seated in an anonymous chair as a passive observer" (DE HANN, 1998, p. 5). In music, the question of meaning, of what music refers to, has not yet reached a consensual answer. Meyer (1956) stated that musical meaning comes from the interaction of each individual with the musical work. He also said that embodied musical meaning had much to do with the listener's expectations, explaining that, for instance, a particular musical gesture could guide the listener to expect an occurring musical result. Moreover, Wayman (2005) pointed out "Scholars and researchers have searched for the meaning of music-making in humans. In addition, much debate exists regarding how composers express meaning through sound as well as how this meaning is experienced by the listener" (WAYMAN, 2005, p. 21). Therefore, one could infer that meaning is frequently constructed on a personal perspective; "Meaning can be ascribed to actions, activities, experiences, and objects according to their value placed on them by the individual” (WAYMAN, 2005, p. 17).

Although sound forms a basic role in making connections and associations with the world around us, new music is often criticised as being "difficult" by listeners. Very often the first (and only) listening of a new music piece is in the context of a première, and the audience needs to be predisposed to listen and to make sense of a piece that has never been listened to before. That is one reason for why new music is often perceived as challenging, and many times generates controversial 
opinions. If we take the example of a live music pop rock concert most audience members know how to react to the band. Often, this is not the case in a new music concert. Carvalho \& Marinho (2010, p. 108) referred that

Public performances of contemporary music within the Western-art tradition are characterized by recurring patterns involving not only repertoire choices, but also behavioural norms that affect performers and audience alike", such as “(...) dress rules, sets of specific gestures (discreet for expressive, dignified repertoire, or ample and exaggerated for virtuosistic repertoire), or behaviour models towards the audience. But the audience is also conditioned by specific rules: silence during performances, applause at specific moments only, indignant stares at prevaricators, and cough at appropriate moments (CARVALHO \& MARINHO, 2010, p. 110).

Music is intrinsically a collaborative art, and new music allows for some non-obvious relationships between composers, performers, and listeners. New music works have been providing unique opportunities for composer/performer collaboration, however no significant research has yet investigated how to further include, engage and promote the participation of the audience into new music pieces or concerts, and specifically research that discusses the composition process itself.

As de Hann (1998, p. 14) mentioned

\footnotetext{
The relationships between the sounds, and the people accordingly involved in the making and/or listening to the sounds, are determined through a natural series of connections which although they may be difficult to quantify, are interconnected through a focus on the creation of a sounding music as a shared activity (DE HANN, 1998, p. 14).
}

Therefore, the composer can re-think ways on how a listener can become part of the performance. The participation of the audience as performer may create unique experiences to the listener, as each element of the public is as actively involved in the music-making as the performers.

\section{“occupied mirrors": the composition process}

The starting point for this paper was the commission of a new music piece for toy piano. When I received this commission, I started to think about an instrument that is very often considered a toy, but it has also been increasingly used as a concert instrument, with specific repertoire written for it. One of the most well-known examples is John Cage's "Suite for Toy Piano", 
written in 1948. Other important works include: "Ancient Voices of Children" written in 1970 by George Crumb, Yann Tiersen’s “La Valse d’Amélie” (2001), “Sonata for Toy Piano” by Michael Finnissy (2006-07), or "under the wood" (2012) for 2 amplified toy pianos and ensemble and "Miles to go" for 4 prepared and amplified toy pianos by Karlheinz Essl.

Nowadays, several pianists, for instance: Philip Thomas, Margaret Leng Tan, Phyllis Chen, Antonietta Loffredo and Isabel Ettenauer, are dedicating a great deal of their time performing on the toy piano, and even commissioning new works to composers. Both performers and composers have widened the instrument's repertoire, including timbral alterations, what is commonly called "extended techniques".

"The fact that music is played with a toy suggests to the listener that something different will happen and they will have a chance to join the game" (LOFFREDO, 2018, p. 121). So, I decided that it would be interesting to include the audience in the piece. This would be the musical bridge between this toy, which was invading the stage as a performative soloist, and the audience itself. In this section, I will not only describe the different stages of the composition process, but also reflect on how each stage calls for different approaches with the audience in mind.

\section{Stage 1 - The starting point for the compositional narrative}

Most of my pieces depart from a very specific starting point, which can emerge from many sources: literature, visual arts, landscapes, details, or any kind of experience. It will be this initial stimulus that will determine my narrative and will structure my compositional material. That is why my titles always arise before I start writing the piece.

The starting point for this piece was a picture (picture 1) that I took in Montreal, Canada, in which one can see in a window the reflection of the street; this later became the narrative idea for my piece, “occupied mirrors”. 
Picture 1 - Photograph of a Montreal window, in Canada.

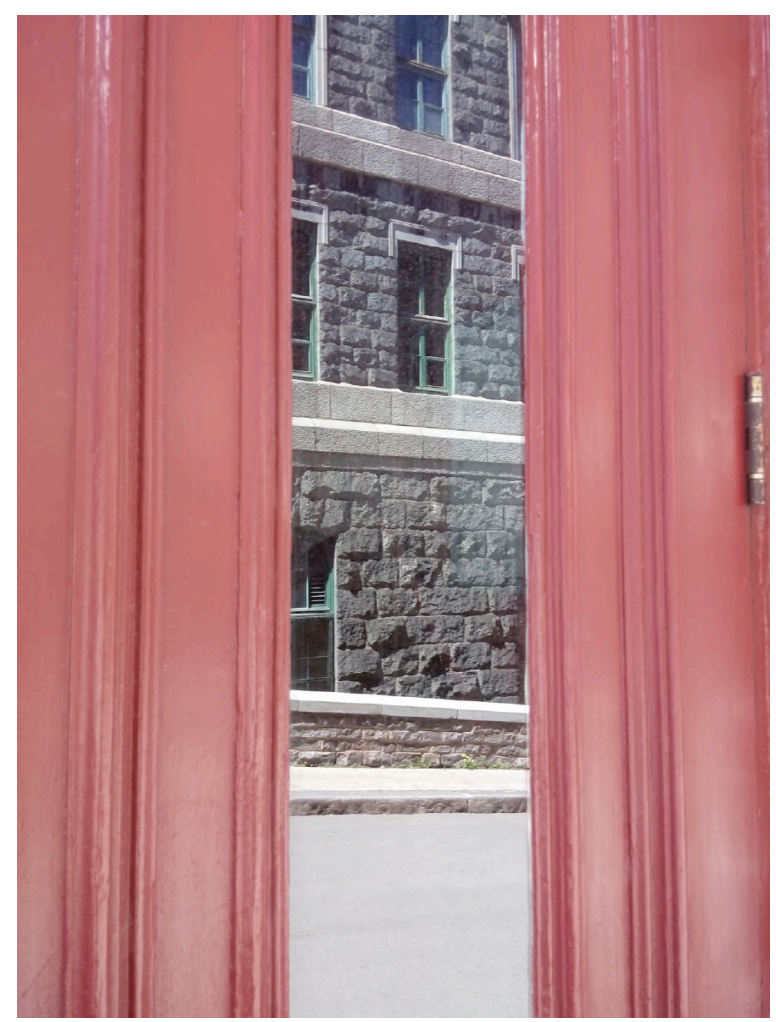

Photograph taken by the author of the paper (2017)

When one looks to the window, it is not possible to see the interior of the house; one can only see the reflection of the street, as if the street itself had become the interior of the house. This led me to think about a stage curtain (as often they are traditionally red as in the picture), and the performance event being occupied by other reflections and/or elements. In this case, the audience would be "occupying" the stage. This is the reason why my piece is called "occupied mirrors", and the paper "occupied reflections: audience as performers". Departing from the unique timber of the toy piano, the main idea for the piece was not only to explore the instrument acoustically, but also to find compositional ways in which I could integrate the audience into the piece. I would do this by asking them to play along, and to actively participate in the performance: my aim was to explore, present and analyse all musical reflections that occurred in my creative process.

\section{Stage 2 - The performance}

The piece was conceived having the performance in mind, and the composition process was very much influenced by that. I decided that the toy piano would play different gestures and 
phrases, and the role of the audience would be to echo, amplify and transform them, in responses that would be related with the musical material that was being listened to.

So, while thinking about the piece, I had to decide how the pianist was going to communicate and perform with the audience during the performance. Therefore, I decided that while entering the concert hall, different sound objects should be randomly distributed to the audience. Before starting the piece, the pianist should briefly explain to the audience how their interaction would be, and what their role would be during the performance of the piece.

In order to trigger the audience participation and interaction with the toy piano, I created three different images (pictures 2, 3 and 4) that would be projected during the performance. These images were presented to the audience, and it was explained how they were related to each sound object, and also the improvisational aspect of their participation. As observed in the pictures 2, 3 and 4 these interventions don't need to follow a traditional score; the idea is that while the pianist plays, the images are triggered, inviting the intervention. For these images/interventions I created three improvisational sound gestures.

The first image to be projected during the performance (picture 2) is a photograph with plastic bags, with the written instruction "Audience: continuous soft sound". When this image appears, the audience members that have plastic bags should improvise with the object, creating a continuous soft sound, accompanying the toy piano. Then, when the audience needs to stop, another projection appears with the word "SILENCE".

Picture 2 - First projection of the piece "occupied mirrors", for toy piano and audience

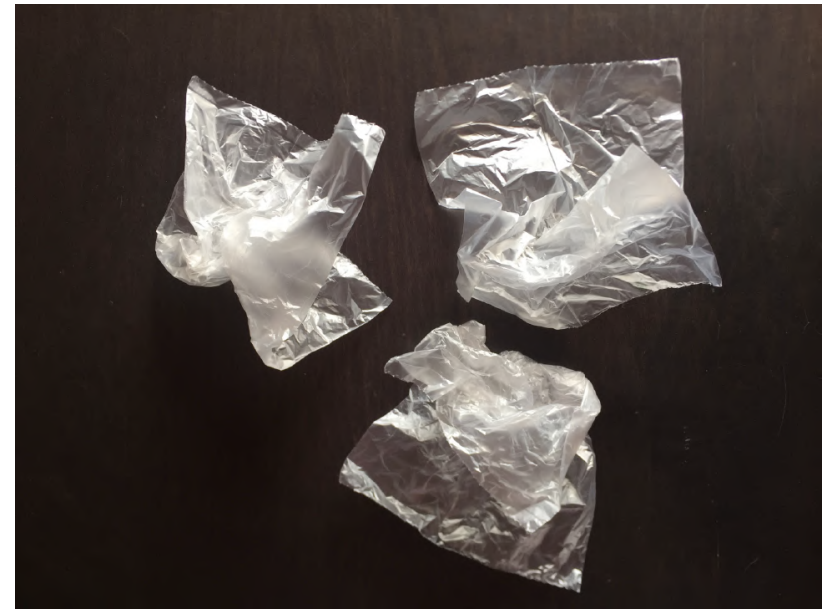

Audience: continuous soft sound

Photograph taken by the author of the paper (2019) 
The second image to be projected (picture 3) is a photograph of two hands rubbing each other; here the instruction given to the audience is not written, but communication is given through the indication of two arrows moving into different directions. The idea is that the entire audience will rub their hands, in any velocity. When the audience needs to stop, a projection appears with the word "SILENCE".

Picture 3 - Second projection of the piece "occupied mirrors", for toy piano and audience

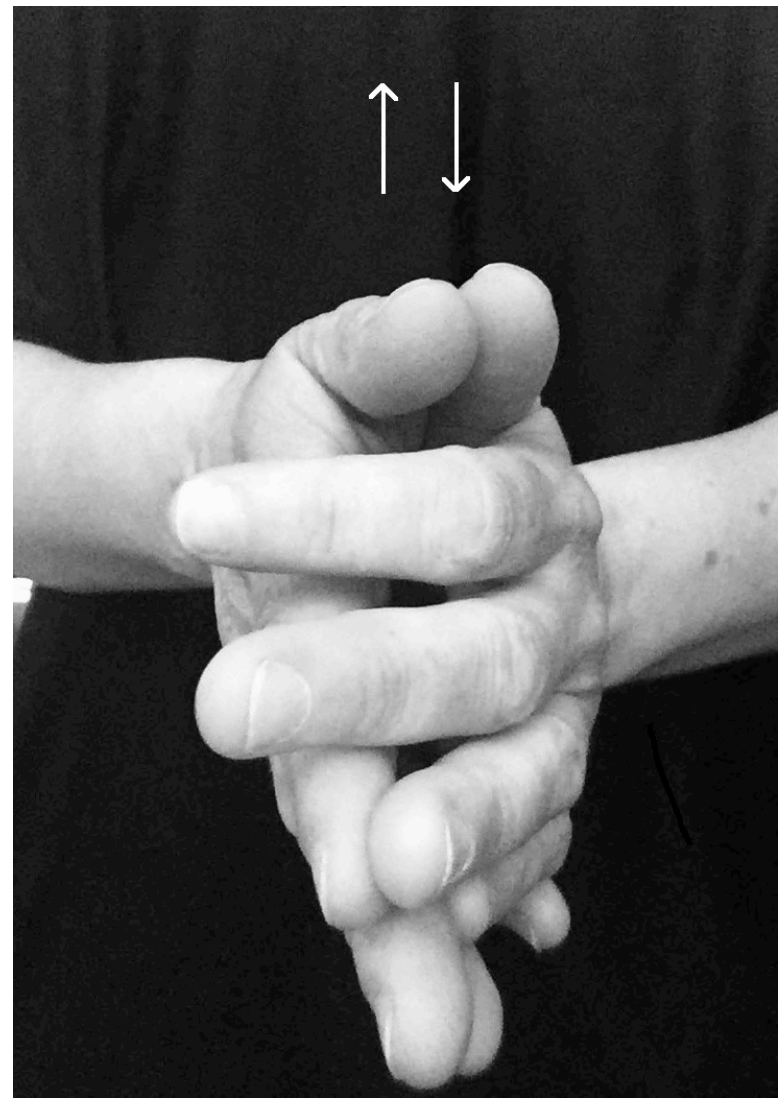

Photograph taken by the author of the paper (2019)

Finally, the third and last image to be projected (picture 4) is a photograph with bubble wrap, with the instruction "Audience: pop + play". When this image appears, the audience members that have bubble wrap should improvise with the object creating a "popping" sound, playing along with the toy piano. Again, when the audience is to stop, another projection will appear with the word "SILENCE". 


\section{Picture 4 - Third projection of the piece "occupied mirrors", for toy piano and audience}

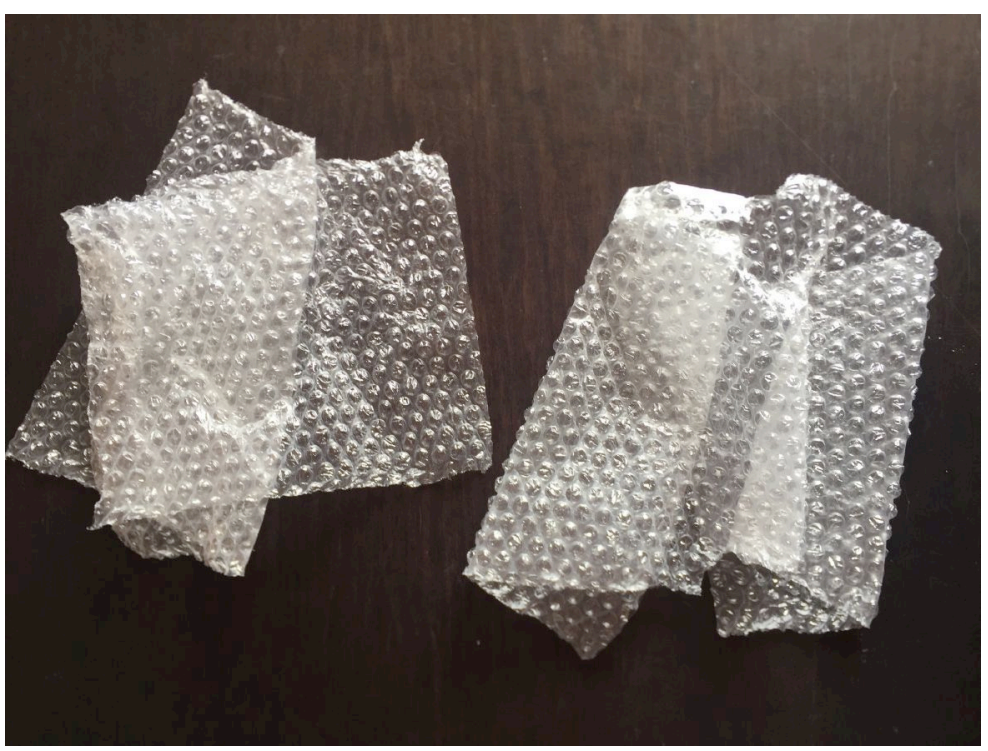

Audience: $p o p+$ play

Photograph taken by the author of the paper (2019)

The intention is that the audience becomes either an extension or a continuous layer of the toy piano's sound world. The written score used by the pianist allows a notation that encourages audience improvisation. With the composer's permission, the audience's instruments may be substituted with similarly sounding material.

\section{$\underline{\text { Stage } 3 \text { - Structure \& compositional material }}$}

\section{The 1st intervention}

In the 1st intervention, the audience improvises using plastic bags. This occurs approximately 30 seconds after the beginning of the piece, and lasts approximately 30 seconds.

First, it is important to mention that apart from playing with the toy piano, the pianist also plays with small objects, such as knitting needles, soft mallets, and a singing bowl. These objects will be slowly presented throughout the piece. The first one to appear is the singing bowl, simultaneously played as a complementary timber sound for the toy piano at the beginning of the piece (figure 1). The singing bowl gives the toy piano the resonant sound that it lacks; it also opens up the possibility for other sounds to emerge within the piece. The intention was that it could also become a referential element to guide the audience. 
Figure 1 - Measure 1-4 of the piece “occupied mirrors", for toy piano and audience

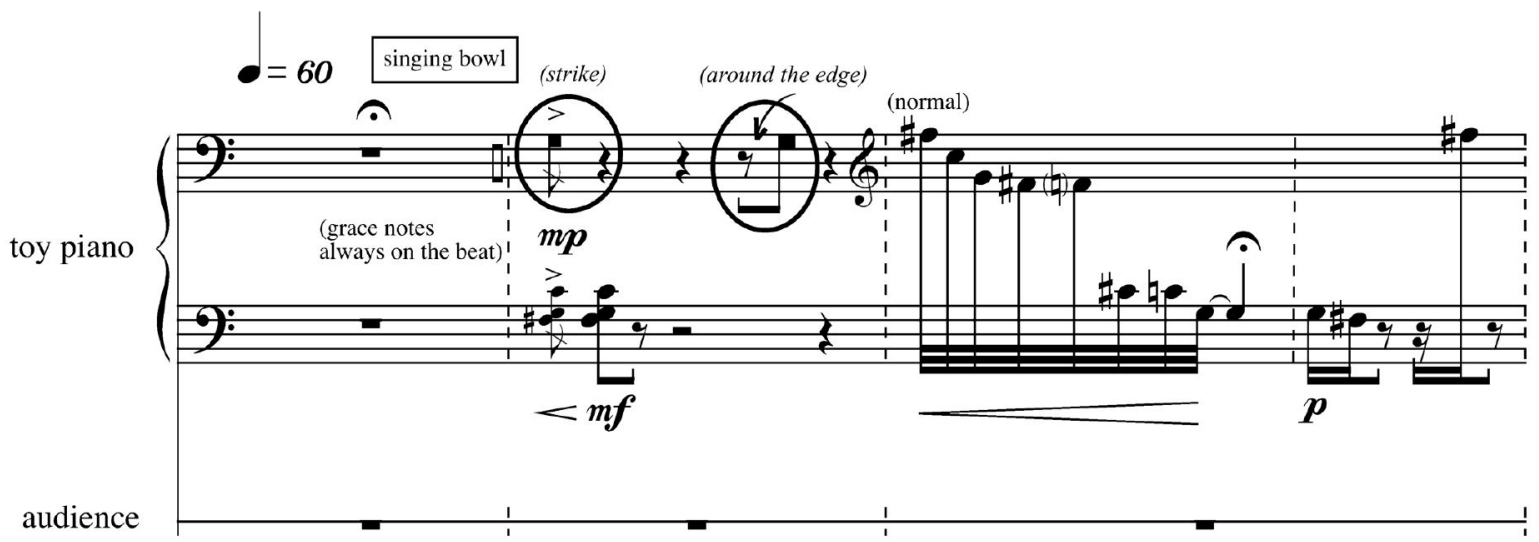

Figure 2 shows how the score was written in order to allow the 1 st audience participation. The improvised section becomes measured in seconds, in order to permit the pianist the necessary freedom to interact. The same occurs with the use of graphic notation. This type of notation allowed me to focus on my main objectives without losing my compositional ideas. For that, I simplified some of the written elements, which helped the pianist's freedom and synchronisation with the audience. This allowed a performance that conveyed my ideas and my compositional intent.

Figure 2 - 1st intervention of the audience in the piece "occupied mirrors", for toy piano and audience

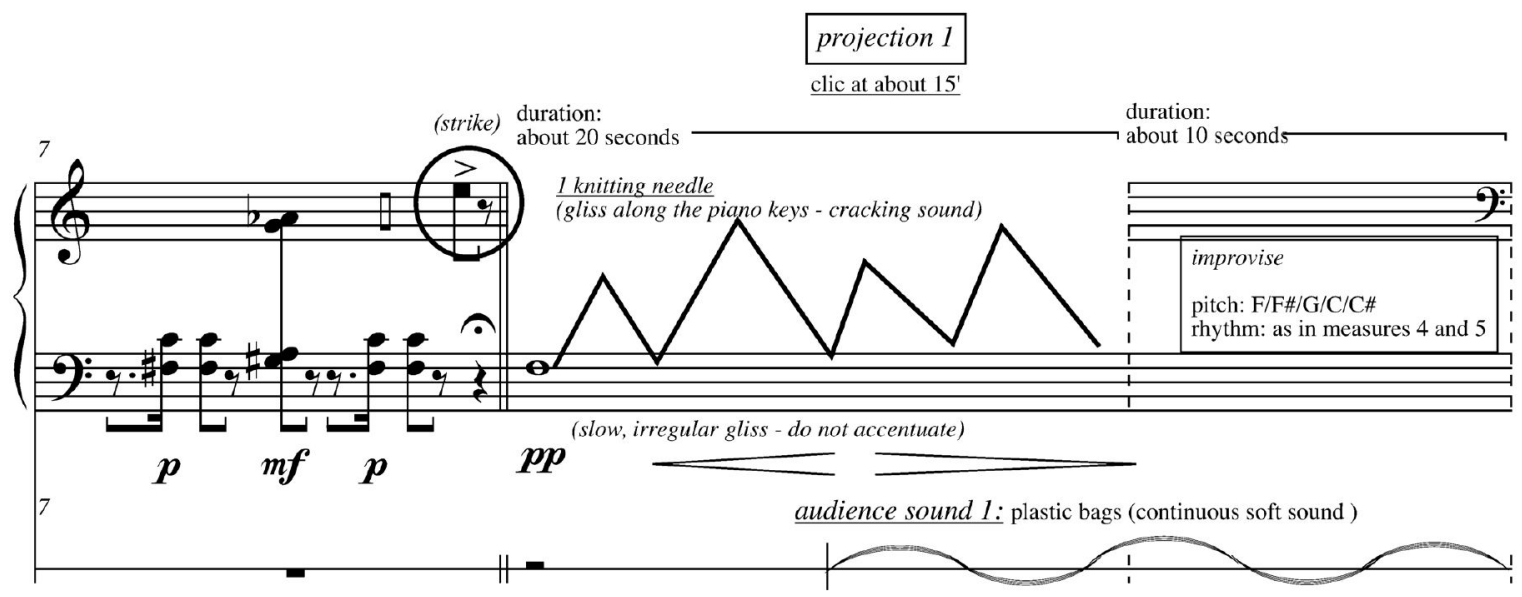

In the $1^{\text {st }}$ intervention the intention is that the audience improvises using plastic bags, creating a continuous soft sound, accompanying the knitting needles glissando played by the pianist 
along the piano keys. This intervention has two purposes: 1) it is a response to the knitting gesture of the pianist; 2) gives transitional time for the pianist to move again to the toy piano sound (last measure of figure 2).

All the audience interventions have the function of assuming the role of other percussion instruments. In this case, the audience has the function of a pedal sound, a continuous sound that toy pianos don't have. This intervention allows time to reflect on what was previously heard, and becomes a bridge for what is to come. This gesture is revisited at the end of the piece, as seen in figure 3 .

Figure 3 - Revisited 1st intervention of the audience in the piece "occupied mirrors", for toy piano and audience
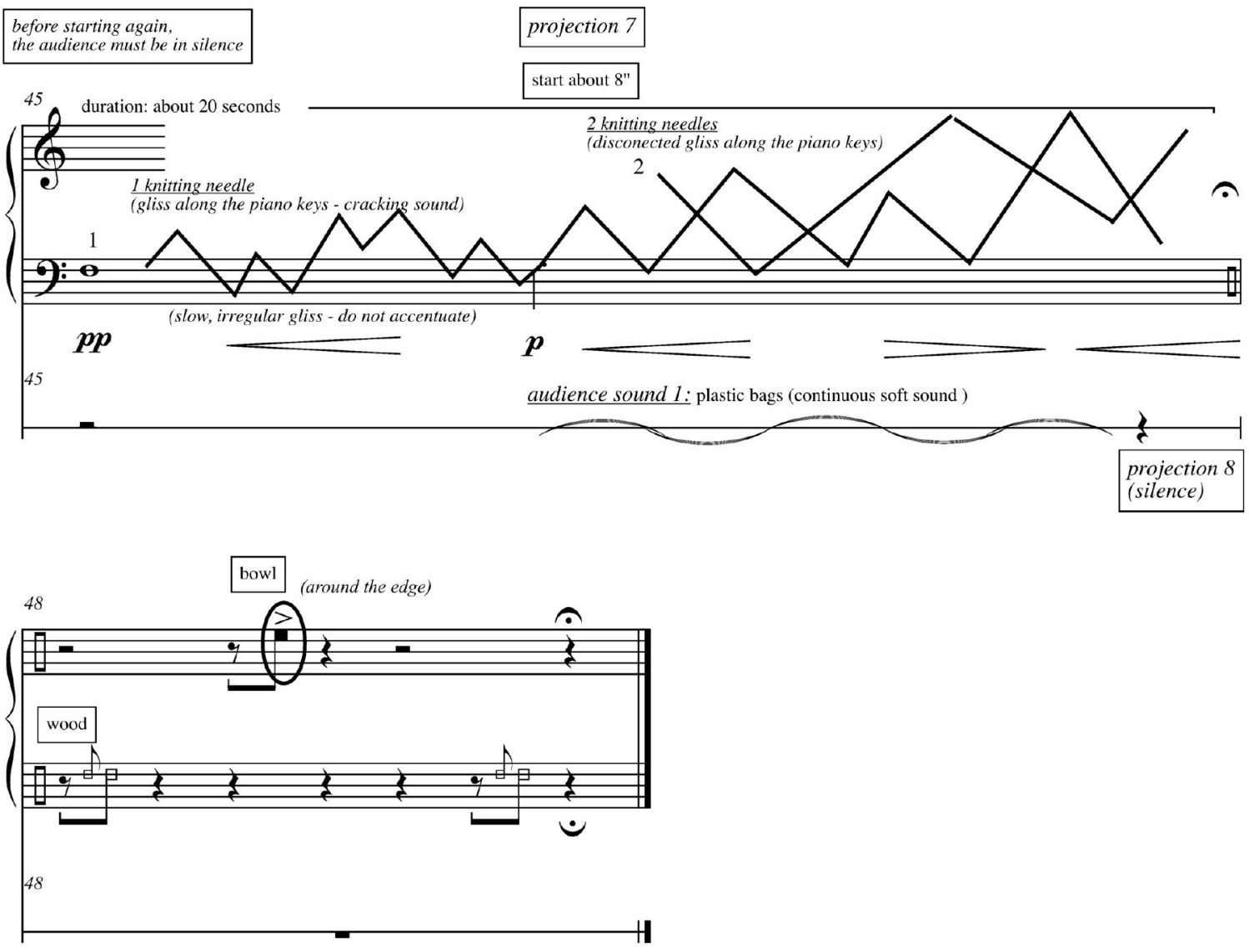

In order to indicate to the audience when to stop an intervention, a projection appears with the word "SILENCE". As indicated in the score, it is the pianist that decides when to stop an audience's improvisation. Figure 4 demonstrates an example that appears in the score. 
Figure 4 - Example of the instruction "silence" in the piece "occupied mirrors", for toy piano and audience

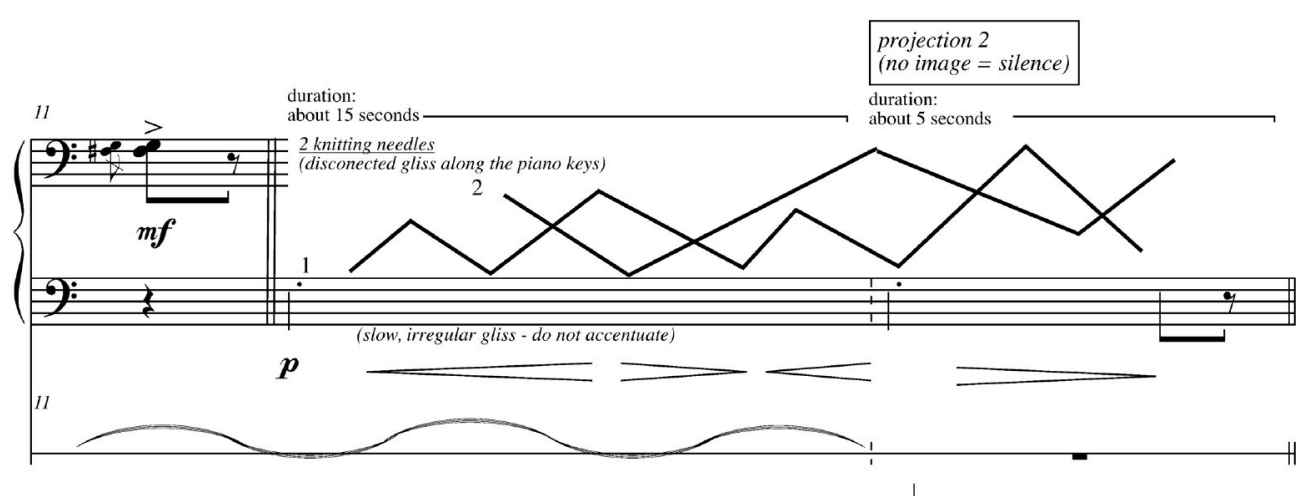

\section{The 2nd intervention}

For the second intervention it is suggested to the audience to gently rub their hands. Body percussion has been used for as long as we can remember, and in several contexts (people clap to music, for instance). It is the only intervention where the entire audience participates at the same time, and where everybody does the same thing, whereas in the other two interventions objects are dispersed throughout the audience. This decision not only allowed everybody to participate simultaneously but, because it is a rather soft sound, gave it an amplified texture.

Analytically speaking, and in relation to the previous sound played by the audience, it relates to it as an echo, a softer reflection of the earlier sound. Therefore, as with the plastic bags, its function is again a pedal sound, that accompanies the improvised trills of the pianist (figure 5).

Figure $5-2^{\text {nd }}$ intervention of the audience on the piece "occupied mirrors", for toy piano and audience

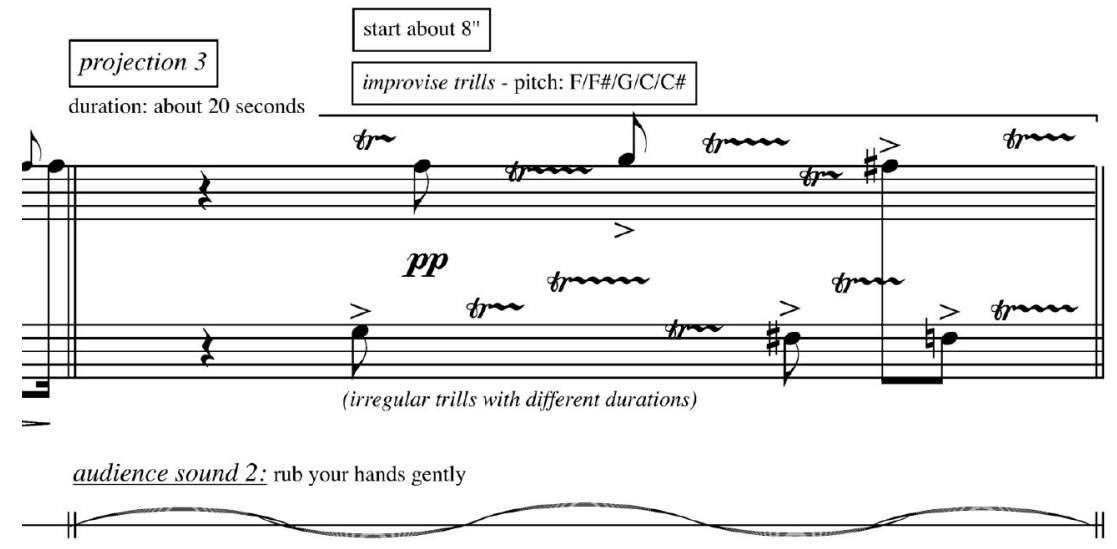




\section{The 3rd intervention}

Finally, in the $3^{\text {rd }}$ intervention, the audience members with bubble wrap should pop it. The idea is to imitate and respond to the pianist's staccato, in order to create an improvised dialogue, which amplifies what is being listened to (figure 6).

Figure $6-3^{\text {rd }}$ intervention of the audience of the piece "occupied mirrors", for toy piano and audience
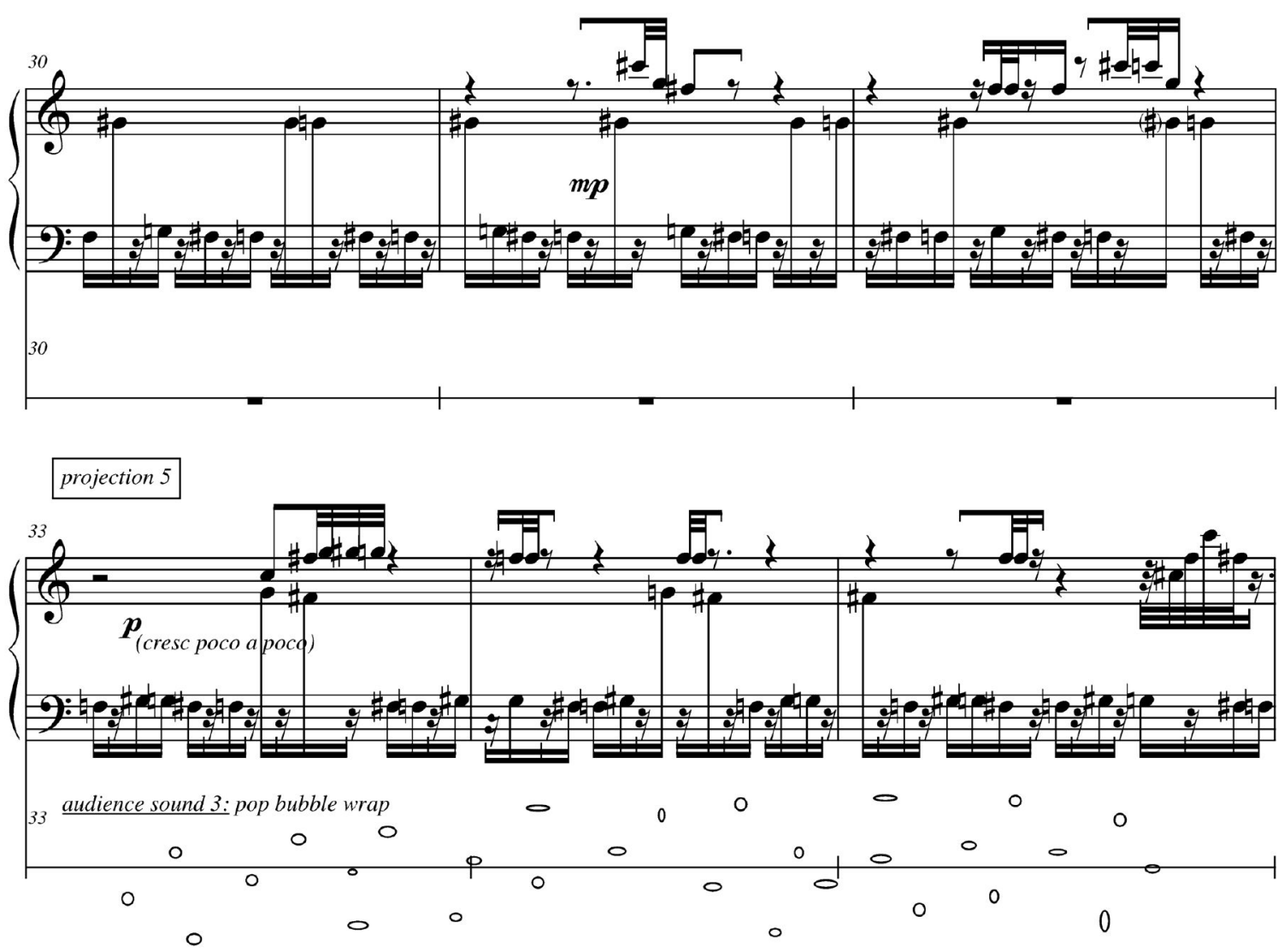

This staccato is related to the other small object used by the pianist, that was not yet mentioned, the soft mallet played on wood. The first time that it is heard is after the $1^{\text {st }}$ intervention of the audience. Firstly, one hears the singing bowl several times; then, the knitting needles along with the piano keys are introduced; and finally, we listen to the sound of wood. Thereafter, and before the $3^{\text {rd }}$ intervention, this sound appears several times, in order to create a relationship between the three types of staccato: the bubble wrap, the wood and the staccato played on the toy piano. 
Figure 7 - First time the sound of wood is listened to in the piece "occupied mirrors", for toy piano and audience

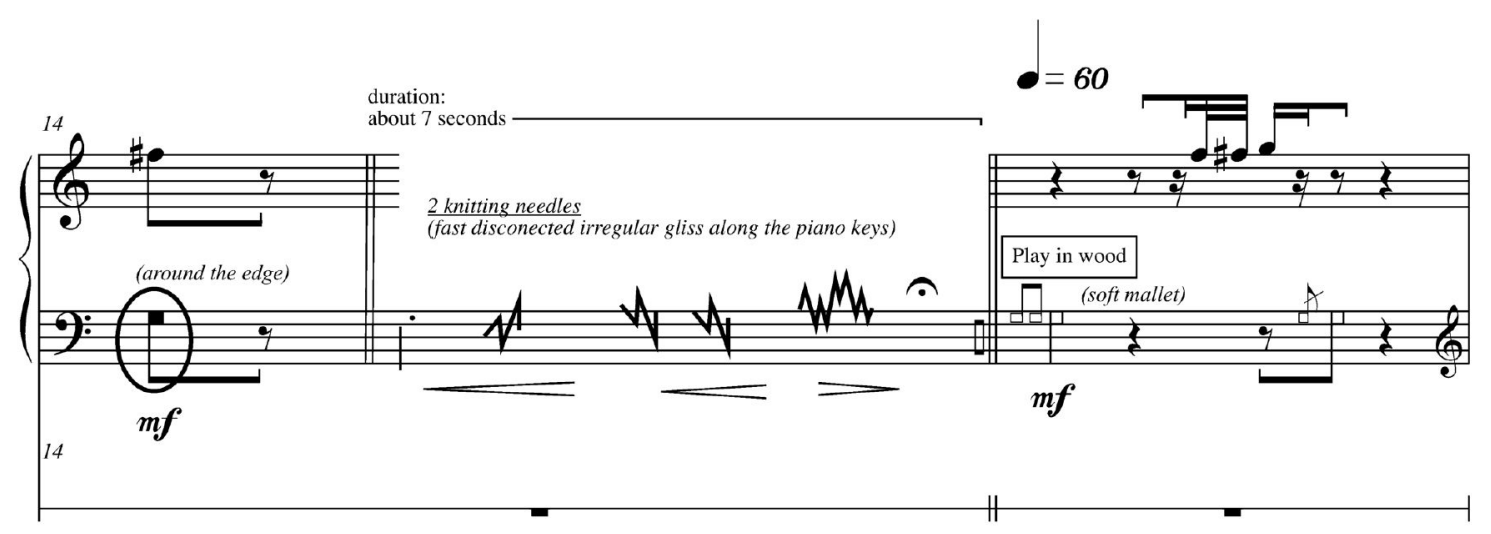

\section{Final conclusion}

“Occupied mirrors", for toy piano and audience, was premièred in July 2019 to an audience of 50 people. In this piece the listener was not only engaged in listening, but also physically participated in making-music, in much the same way as the performer. Together, performer and audience produced the final outcome, as they both actively participated in the construction of the sound. As the audience's role was altered, that allowed space to create a meaningful experience and a very unique synergy. My intention was not only to guide the listener during the performance, but also, simultaneously, to allow them to experience something different by participating in the musicmaking.

In this piece what was asked from the audience opened up a new music experience, as they had to follow instructions from the pianist, and actively participate in the construction of the sound. The use of indeterminate and graphic notation in the score allowed for a more flexible piece, and gave space for the audience to participate.

It is a fact that creativity is a fundamental element in the construction of a positive musical experience. So, by allowing creative participation from the audience, by engaging the audience in the music making process, by exploring this kind of interaction between the musicians and the audience, we can lay out an alternative way to reach future audiences. Also, it could allow further discussion on how listeners recollect, perceive and describe new music, and therefore amplify current knowledge on the development of how meaning can be constructed. 
In this paper it was not my intention to evaluate the audience's participation experience, but mainly to share alternative compositional approaches, when having the audience in mind. However, after the première several people came to me at the end of the concert saying that they really enjoyed participating in the piece. The listeners-performers referred that their participation made them more involved in the music, as it engaged their imagination in an emotional way.

By including the audience in my piece my intention was not only to guide the listener experience during the performance, but also to create an experience, which could be easily remembered, and evoke different types of memories; the piece becomes something that can be read and interpreted from several angles, as by participating different memories emerge.

It is my believe that engaging the audience in the music making process, and exploring this kind of interaction between the musicians and the public, could approximate and attract audiences to new music.

\section{ACKNOWLEDGMENT}

This research was funded by the project "Xperimus - Experimentation in music in Portuguese culture: History, contexts and practices in the 20th and 21st centuries", co-financed by the European Union, through the Operational Programme Competitiveness and Internationalization, in its ERDF component, and by national funds, through the Portuguese Foundation for Science and Technology. Department of Communication and Art, University of Aveiro, Portugal, Instituto de Etnomusicologia - Centro de Estudos em Música e Dança, Portugal.

\section{REFERENCES}

CARVALHO, Sara; MARINHO, Helena. Ritual and transgression: A Case Study in New Music. E-Cadernos, Centro de Estudos Sociais da Universidade de Coimbra, n.8, pp.108-120, 2010. Available at: $<$ http://www.ces.uc.pt/e-cadernos/media/ecadernos8/07 - Sara Carvalho e Helena Marinho 12.04.11 FINAL.pdf>. Accessed on: 30 April 2019.

COOK, Nicholas. Between Process and Product: Music and/as Performance. Music Theory Online, v.7, n.2, 2001.

DE HANN, Simone. The Relationship between the Composer, Performer and Listener in Twentieth Century Music-Making - Inaugural professorial lecture. Griffith University, Queensland, Australia, 
1988. Available at: $<$ http://hdl.handle.net/10072/368708 $>$. Accessed on: 2 May 2019.

LOFFREDO, Antonietta. The Toy Piano. Bologna: Ut Orpheus, 2018.

MEYER, Leonard. Emotion and Meaning in Music. Chicago: University of Chicago Press, 1956.

KENDALL, Roger; CARTERETTE, Edward. The Communication of Musical Expression. Music Perception v.8, n.2, pp.129-163, 1990.

SERAFINE, Mary Louise. Music as Cognition: The Development of Thought in Sound. Columbia University Press, New York, 1988.

WAYMAN, Virginia. The meaning of the music education experience to middle school general music students. Dissertation (Doctor of Philosophy with a Major in Music). Faculty of the School of Music and Dance, University of Arizona, 2005. Available at: $<$ https://docplayer.net/41698818The-meaning-of-the-music-education-experience-to-middle-school-general-music-studentsvirginia-elaine-wayman.html >. Accessed on: 29 April 2019.

\section{ABOUT THE AUTHORS}

Sara Carvalho is a composer and a lecturer in Aveiro University, and a fellow researcher of INET-md, Portugal. She is interested in the interaction of different Performing Arts, and all aspects associated with gesture, audience as performers and performer-composer collaboration. Her folio has over 60 pieces that are played regularly, including commissions by ensembles of international merit, and prestigious institutions. Several of her pieces are available on CD and many of her scores are published by the Portuguese Music Information Centre. Her research work is presented at international conferences, and is published in several journals and book chapters. ORCID: https://orcid.org/0000-0003-4391-8498. E-mail: scarvalho@ua.pt 